\title{
Review of Denitrogenation of Algae Biocrude Produced by Hydrothermal Liquefaction
}

\author{
Jinsheng Sun ${ }^{1} \cdot$ Jie Yang $^{1} \cdot$ Ming Shi $^{2}$
}

Received: 10 May 2016/Revised: 19 August 2016/ Accepted: 28 August 2016/Published online: 25 April 2017

(C) The Author(s) 2017. This article is an open access publication

\begin{abstract}
Recently, algae biocrude has drawn considerable attention as algae are considered to be one of the major fuel feedstocks of the future. Based on some impressive results achieved under appropriate conditions, the algae hydrothermal liquefaction (HTL) process has proven to be energy efficient. However, the HTL of biocrude is characterized by a high nitrogen content, which prevents its use in the field of transportation due to the associated nitrogen oxide emissions. Despite this toxicity, few research efforts have focused on the denitrogenation of algae biocrude. In this study, we review the effect of different strain-specific operation parameters and process upgrades with respect to the nitrogen content of biocrude. To achieve denitrogenation, chemical engineering may be required, although some improvements in biocrude properties have been achieved in a number of process upgrades. The use of similar successful pathways has the potential to improve the field of HTL biocrude denitrogenation. These methods, including the adsorptive and extractive denitrogenations of fossil fuels and the hydrodenitrogenation of the main nitrogen compounds, are helpful for developing a better understanding of the potential of denitrogenation for algae HTL biocrude. We also recommend the use of some available catalysts and corresponding operation parameters to promote continued research on denitrogenation.
\end{abstract}

Jinsheng Sun

jssun2006@vip.163.com

1 School of Chemical Engineering and Technology, Tianjin University, No. 135 Ya Guan Road, Jinnan District, Tianjin 300354, China

2 Wuhan Jinzhong Petrochemical Engineering CO., LTD, Wuhan 430223, China
Keywords Algae $\cdot$ Hydrothermal liquefaction · Biocrude · Upgrading · Denitrogenation
Abbreviations
HTL Hydrothermal liquefaction
DCM Dichloromethane
HDN Hydrodenitrogenation
MOF Metal organic framework
$T_{\mathrm{c}} \quad$ Critical temperature of water $\left({ }^{\circ} \mathrm{C}\right)$
$P_{\mathrm{c}} \quad$ Critical pressure of water $(\mathrm{kPa})$

\section{Introduction}

The twin challenges of climate change and the energy crisis, resulting from the unfettered energy demands of modern industry, have led to the development of biofuel production from biomass, which is associated with fewer emissions [1-3]. Biomass, as a renewable resource, fixes carbon dioxide in the atmosphere through photosynthesis during growth, and is regarded as an alternative feedstock for fuel. Biomass resources include terrestrial and aquatic plants, food materials, biowastes, algae and bacteria. Of these, algae grow in saline or fresh water and can be cultivated on non-arable lands. As such, they qualify as candidates because of their advanced photosynthetic efficiency, high biomass production, rapid growth speed, low environmental impact and low competition for food $[4,5]$. Recently, the production of biocrude from algae biomass has been extensively investigated via processes of fermentation [6, 7], transesterification [8, 9], pyrolysis [10-13], gasification [14, 15], liquefaction [16-19], and carbonization [20, 21]. Of these methods, hydrothermal liquefaction (HTL) is considered to be a promising method for processing feedstock with high conversion efficiency 
and has the advantage of treating wet materials without the need for drying [22].

A typical HTL process is conducted around a critical point $\left(T_{\mathrm{c}}=373.95^{\circ} \mathrm{C}\right.$ and $\left.p_{\mathrm{c}}=22.064 \mathrm{MPa}\right)$ of water, and sometimes uses reducing gases such as $\mathrm{H}_{2}$ and $\mathrm{CO}$. A separation procedure is performed to recover biocrude from the product after liquefaction. After releasing gaseous products, organic solvents are added to dissolve the biocrude, followed by an organic phase that easily separates the aqueous and solid phases by decantation and filtration. These solvents typically include dichloromethane (DCM), chloroform, acetone, and toluene. Then, biocrude is obtained by evaporating the solvent after phase separation. In this paper, we base the calculated biocrude yields on dry algae if no specific description is provided.

The HTL of algae was first reported by Dote et al. [23] in 1994, followed by Minowa et al. [24] in 1995. In the years that followed, a growing number of studies and papers on the HTL of algae focused on the effects of operating parameters, algae types, and catalysts on biocrude's characteristics. For example, Matsui et al. [25] converted Spirulina into biocrude by various solvents over an iron catalyst. Some impressive results have been achieved under appropriate conditions. The co-liquefaction of algae with coal was also reported [26, 27], but is beyond the scope of this review. Besides HTL, we also address liquefaction processes in subcritical and supercritical alcohols in this review [28-30]. Table 1 summarizes the optimal conditions and results of existing studies.

During HTL, the proteins that abound in algae may also be converted into large amounts of nitrogenous heterocyclic compounds in biocrude, such as pyridine and quinoline, which affect smell, combustion, and various other properties. As such, understanding the degradation of proteins is important [31-33]. As shown in Fig. 1, nitrogen compounds are produced by Maillard reactions between sugars and amino acids [34]. Amino acids linked by peptide bonds are the building blocks of proteins. These peptide bonds are $\mathrm{C}-\mathrm{N}$ bonds between the carboxyl and amine groups present in all amino acids, and are known to rapidly hydrolyze in hydrothermal systems [35]. In fact, differences in the chemical structures of amino acids yield divergent reaction paths. Since many amino acids contain the same peptide bonds, during HTL, they undergo similar decarboxylation and deamination reactions to produce carboxylic acids, aldehydes, carbonic acid, ammonia, and organic amines [36].

A biocrude that is high in nitrogen requires more extensive upgrading before it is suitable for use in the transportation industry or conventional refining, which increases the cost and energy inputs required to produce the final products [37]. Table 2 summarizes existing HTL research. To our knowledge, only a limited number of reviews have addressed the denitrogenation of algae biocrude. In this review, we summarize the above-mentioned work to better understand this field. In addition, we present the latest achievements in the chemical engineering field in which denitrogenation has been successfully employed, including the hydrodenitrogenation (HDN) of nitrogen compounds and the adsorptive and extractive denitrogenations of fossil fuel.

\section{Biocrude Production by HTL of Algae}

The biochemical composition (lipids, proteins, and carbohydrates) in algae generally varies among species, and the growth of a given alga can be affected by different environments. Table 3 shows the typical compositions of four most investigated algae strains. Taking chlorella as an example, there are about ten major species (with varieties of up to 100 species) distributed across different regions of the world, each of which has different lipid and protein contents. More lipids can be induced in nutrient-deficient conditions, whereas more proteins can be produced in nutrient-rich conditions. Under specific conditions, Chlorella pyrenoidosa is a low-lipid and high-protein algae [38], and its counterpart, Chlorella sorokiniana, has the opposite characteristics [39].

The compositions of different algae strains have important influences on the composition of liquefied biocrude, as well as its reaction route [40, 41]. The biocrude production capability has the following order: lipids $>$ proteins $>$ carbohydrates [42]. Neveux et al. [43] studied six species of marine and freshwater green macroalgae that had been cultivated in outdoor tanks, and subsequently converted them to biocrude via HTL in a batch reactor. The authors then assessed the influence of the biochemical composition of the biomass on the biocrude yield. The results showed that freshwater Oedogonium $(35.9 \%)$ and marine Derbesia $(33.4 \%)$ had the highest biocrude yields of all species, based on their ash-free dry weight, as they had the highest proportion of lipids that are efficiently converted to biocrude through the rapid hydrolysis of triglycerides. Lopez et al. [44] analyzed the influence of strain-specific parameters (cell structure, biochemical composition and growth environment) on the HTL of microalgae. The authors found strain-specific parameters to play a role at higher temperature. In addition, the nitrogen content of algae can also vary significantly according to the species, environmental conditions, and post-harvest processing, so these parameters greatly influence the nitrogen content of the biocrude. Thus, the influences of different strain-specific and operational parameters on biocrude properties must be considered. In this section, we summarize these aspects and their biocrude upgrading results via HTL according to their algae strains. 
Table 1 Summary of optimal experimental conditions and results of HTL of algae

\begin{tabular}{|c|c|c|c|c|c|c|c|c|}
\hline \multirow[t]{2}{*}{ Algae type } & \multicolumn{4}{|l|}{ Conditions } & \multirow{2}{*}{$\begin{array}{l}\text { Biocrude } \\
\text { yield }(\%)\end{array}$} & \multirow{2}{*}{$\begin{array}{l}\text { Nitrogen } \\
\text { content }(\%)\end{array}$} & \multirow{2}{*}{$\begin{array}{l}\mathrm{HHV} \\
(\mathrm{MJ} / \mathrm{kg})\end{array}$} & \multirow[t]{2}{*}{ References } \\
\hline & Temperature $\left({ }^{\circ} \mathrm{C}\right)$ & $\begin{array}{l}\text { Residence } \\
\text { time (min) }\end{array}$ & Catalyst type & Extractant & & & & \\
\hline \multirow[t]{9}{*}{ Nannochloropsis } & 350 & 60 & Water only & DCM & 43 & 3.9 & 39 & {$[45]$} \\
\hline & 350 & 60 & $\mathrm{Pd} / \mathrm{C}$ & DCM & 57 & 3.88 & 38.6 & {$[46]$} \\
\hline & 350 & 60 & Water only & Decane & 39 & 4.44 & NR & {$[47]$} \\
\hline & 350 & 60 & Water only & DCM & 34.3 (daf) & 4.1 & 34.5 & {$[48]$} \\
\hline & 350 & 30 & Water only & Acetone & 46 & 2.75 & 38.1 & [49] \\
\hline & 600 & 1 & Water only & DCM & 66 (daf) & 6.92 & 34.51 & {$[50]$} \\
\hline & 300 & 60 & Water only & DCM & 40.6 & 6.59 & 39.6 & {$[51]$} \\
\hline & 340 & 30 & $\mathrm{Ni}-\mathrm{Mo} / \mathrm{Al}_{2} \mathrm{O}_{3}$ & DCM & 78.5 & 4.88 & 37.53 & [54] \\
\hline & 260 & 60 & Water only & Acetone & 55 & 5.4 & 31.5 & [56] \\
\hline \multirow[t]{9}{*}{ Chlorella } & 350 & 60 & $\mathrm{Na}_{2} \mathrm{CO}_{3}$ & DCM & 27.3 (daf) & 4.9 & 37.1 & [58] \\
\hline & 280 & 120 & Water only & Toluene & 39.4 & NR & 35.4 & [59] \\
\hline & 300 & 60 & Water only & DCM & 23.4 & 0.78 & 40.8 & {$[39,60]$} \\
\hline & 240 & 30 & Ethanol & Acetone & 71.3 & NR & NR & [28] \\
\hline & 300 & 30 & Ethanol & Acetone & NR & 8.7 & 36.19 & [28] \\
\hline & 350 & 60 & $\mathrm{Pt} / \mathrm{Al}_{2} \mathrm{O}_{3}$ & DCM & 38.9 (daf) & 5.6 & 37.9 & [48] \\
\hline & 350 & 3 & Water only & DCM & 41.7 (daf) & 7.7 & 33.8 & {$[61]$} \\
\hline & 280 & 60 & Water only & Toluene & 42.8 & NR & NR & [41] \\
\hline & 220 & 90 & Water only & Acetone & 82.9 & 0.3 & 34.9 & [56] \\
\hline \multirow[t]{9}{*}{ Spirulina } & 250 & 3 & Water only & DCM & NR & 3.5 & 30.7 & [61] \\
\hline & 350 & 60 & Water only & Acetone & 39.9 & 6.3 & 35.3 & [64] \\
\hline & 350 & 60 & Water only & Acetone & 39.93 & 6.2 & 31.5 & [65] \\
\hline & 300 & 30 & Water only & DCM & 32.6 (daf) & 6.5 & 33.2 & {$[62]$} \\
\hline & 300 & 30 & Water only & DCM & 31 & 8.1 & 35.8 & [63] \\
\hline & 360 & 20 & Water only & Acetone & NR & 7.46 & 39.83 & [57] \\
\hline & 360 & NR & FeS/ethanol & Ethanol & NR & 9.64 & 37.13 & [29] \\
\hline & 310 & 30 & Water only & Acetone & 30 & 7.66 & 35.2 & [49] \\
\hline & 350 & 60 & $\mathrm{Na}_{2} \mathrm{CO}_{3}$ & DCM & 20 (daf) & 4.6 & 34.8 & [58] \\
\hline \multirow[t]{3}{*}{ Dunaliella tertiolecta } & 360 & 30 & Water only & Chloroform & 36.9 & 4.97 & 26.62 & {$[67]$} \\
\hline & 360 & 50 & $\mathrm{Na}_{2} \mathrm{CO}_{3}$ & Chloroform & 25.8 & 3.71 & 30.74 & {$[68]$} \\
\hline & 320 & 30 & Ethanol-water & Chloroform & 64.68 (daf) & 5.35 & 34.96 & [69] \\
\hline \multirow[t]{2}{*}{ Enteromorpha prolifera } & 300 & 30 & $\mathrm{Na}_{2} \mathrm{CO}_{3}$ & DCM & 23.0 & 5.76 & 29.89 & {$[72]$} \\
\hline & 320 & 15 & Ethanol & DCM & 36.5 & 7.71 & 30.37 & {$[30]$} \\
\hline Microcystis viridis & 340 & 30 & $\mathrm{Na}_{2} \mathrm{CO}_{3}$ & Chloroform & 33 & 7.1 & 31 & [73] \\
\hline Sargassum & 340 & 15 & Water only & Chloroform & 32.1 & 2.45 & 27.1 & [74] \\
\hline Desmodesmus & 375 & 5 & Water only & DCM & 49.4(daf) & 6.3 & 35.4 & [34] \\
\hline Laminaria saccharina & 350 & 15 & Water only & DCM & 19.3 & 4.9 & 36.5 & {$[76]$} \\
\hline Golenkinia sp. & 300 & 60 & Water only & DCM & 31.2 & 6.56 & 37.0 & [51] \\
\hline Tetraselmis sp. & 350 & 5 & Water only & DCM & 65 & 5 & 35 & [71] \\
\hline
\end{tabular}

$N R$ not reported, daf dry ash free basis

\section{HTL of Algal Biomass for Biocrude}

The liquefaction of Nannochloropsis has been extensively studied with respect to the production of biocrude [45-56] and some research results are provided as follows. Brown et al. [45-47] liquefied Nannochloropsis for producing biocrude under various conditions. The authors achieved a maximum biocrude yield of $57 \%$ at $350{ }^{\circ} \mathrm{C}$ for $60 \mathrm{~min}$ with a 50\% (daf) $\mathrm{Pd} / \mathrm{C}$ catalyst, and the biocrude also contained the lowest nitrogen content $(3.88 \%)$ of all their tests. It seemed to the authors that the Pt/C catalyst not only facilitated liquefaction but also supported denitrification. 
Fig. 1 Fate of protein during HTL

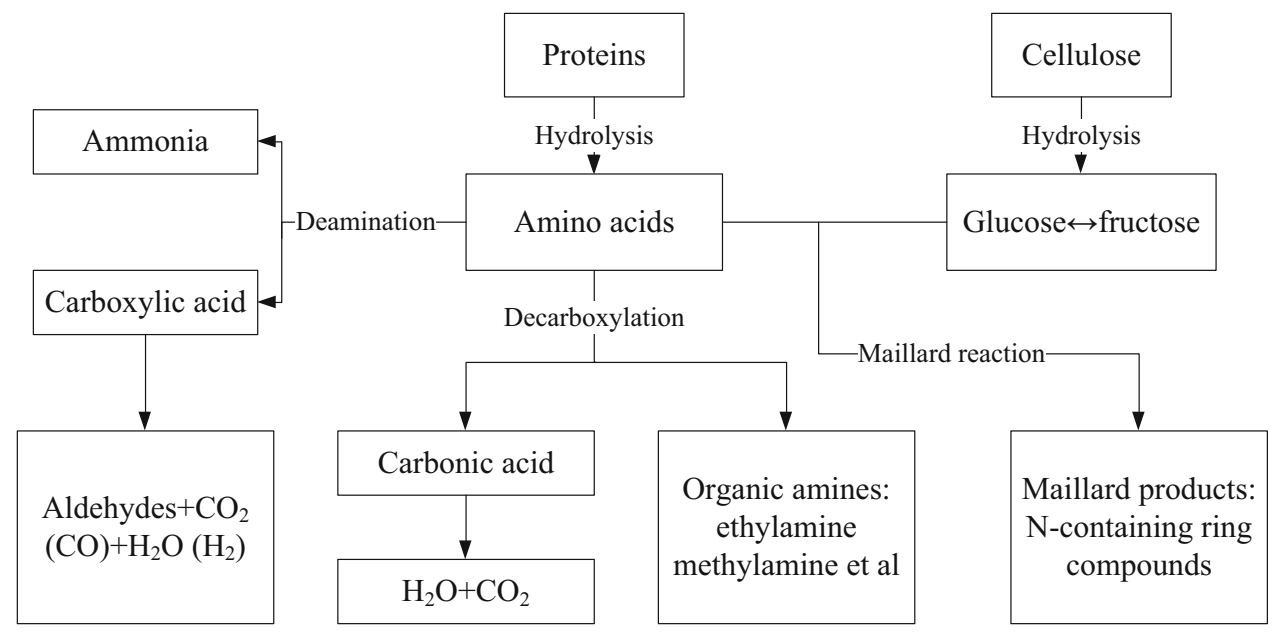

Biller et al. [48] carried out the HTL of Nannochloropsis oculata at $350{ }^{\circ} \mathrm{C}$ for $60 \mathrm{~min}$ by several catalysts, including $\mathrm{Co} / \mathrm{Mo}, \mathrm{Ni}$, and $\mathrm{Pt}$, which were supported on $\gamma-\mathrm{Al}_{2} \mathrm{O}_{3}$. The nitrogen content was efficiently decreased by the $\mathrm{Ni}$ and Pt catalysts, and a higher heating value (HHV) was also achieved compared with the liquefaction process in which only water was used. Toor et al. [49] converted Nannochloropsis salina into biocrude using acetone as the extraction agent. Unlike Duan [46] and Biller et al. [48], the authors obtained biocrude at $350{ }^{\circ} \mathrm{C}$ for $30 \mathrm{~min}$ with a significantly low nitrogen content of $2.75 \%$. This low nitrogen content might be attributed to the algae biomass whose nitrogen content was $2.9 \%$. A fast liquefaction of Nannochloropsis was performed by Faeth et al. [50] who achieved a high biocrude yield of $66 \%$ for a 1-min reaction duration at a $600{ }^{\circ} \mathrm{C}$ set-point temperature. Unfortunately, this biocrude had a high nitrogen content $(6.92 \%)$ and a low HHV $(34.51 \mathrm{MJ} / \mathrm{kg})$ due to its short reaction time. In the preparation process, large molecules were fully broken into small molecules, which required a longer processing time, and amino acids were converted into ammonia or water soluble compounds.

In many types of Chlorellas, the Chlorella sp. may be considered to be a high-lipid and low-protein microalgae (lipid 59.9\%, protein $9.3 \%$ ) under certain conditions, and the biocrude yield produced via HTL with the reducing gas $\mathrm{H}_{2}$ reached $82.9 \%$ [56]. The HHV and nitrogen contents of biocrude by this process are $34.9 \mathrm{MJ} / \mathrm{kg}$ and $0.3 \%$, respectively. Such a high yield may be attributed to the $220{ }^{\circ} \mathrm{C}$ reaction temperature since carbonization and coking were dominant at $300{ }^{\circ} \mathrm{C}$ during the HTL of Chlorellas, due to their higher lipid content and the more rapid hydrolysis process. Polymerization reactions are more active at higher temperatures [57]. The low biocrude nitrogen content could mainly be attributed to the low nitrogen content $(1.9 \%)$ of the algae itself and the longer reaction time $(90 \mathrm{~min})$. Under these conditions, organic nitrogen compounds can be fully transferred to a water phase or converted into gas products such as $\mathrm{NH}_{3}$ or $\mathrm{HCN}$ [33].

Ross et al. [58] studied the HTL of Chlorella vulgaris with alkali and organic acids as catalysts. They produced biocrude with a higher yield, a higher HHV, and a lower nitrogen content using alkali catalysts instead of organic acid at high temperature. Biller et al. [48] also studied this process using metal catalysts that included $\mathrm{Co} / \mathrm{Mo}$, Pt, and $\mathrm{Ni}$, which would imply that all the catalysts could significantly promote the reduction of biocrude's nitrogen content, especially Ni. Zhang et al. [28] also liquefied the same microalgae strain using ethanol as a solvent with heterogeneous catalysts. The lowest biocrude nitrogen content of $8.7 \%$ was achieved at $300{ }^{\circ} \mathrm{C}$ for $30 \mathrm{~min}$ in a hydrogen atmosphere. The big difference in nitrogen content achieved by Ross et al. [58] might be due to the fact that nitrogen could be removed more effectively as ammonia in water rather than in ethanol. Moreover, the higher biocrude yield may be attributed to the reaction of the algae biomass with ethanol.

Compared with Nannochloropsis, Chlorella is also an important raw material for the production of biocrude [59]. Chakraborty et al. [39, 60] developed a unique sequential hydrothermal treatment process for the extraction of polysaccharides from the green alga Chlorella sorokiniana, and the liquefaction of the extracted biomass to obtain biocrude. Interestingly, this biocrude had a very low nitrogen content of $0.78 \%$, which is related to the low nitrogen content of the algae biomass (see Table 3). Jazrawi et al. [61] liquefied Chlorella at a continuous pilotscale plant and obtained a maximum biocrude yield of $41.7 \%$ at $350{ }^{\circ} \mathrm{C}$ for $3 \mathrm{~min}$. The nitrogen content and HHV of the biocrude were $7.7 \%$ and $33.8 \mathrm{MJ} / \mathrm{kg}$, respectively. As with the results by Faeth et al. [50], the short retention time of this process possibly increased the biocrude nitrogen content due to the fact that transferring organic 
Table 2 Summary of optimal experimental conditions and results of upgrading of algae

\begin{tabular}{|c|c|c|c|c|c|c|c|c|}
\hline \multirow[t]{2}{*}{ Algae type } & \multicolumn{4}{|l|}{ Conditions } & \multirow{2}{*}{$\begin{array}{l}\text { Biocrude yield } \\
(\%)\end{array}$} & \multirow{2}{*}{$\begin{array}{l}\text { Nitrogen } \\
\text { content }(\%)\end{array}$} & \multirow{2}{*}{$\begin{array}{l}\mathrm{HHV} \\
(\mathrm{MJ} / \mathrm{kg})\end{array}$} & \multirow[t]{2}{*}{ References } \\
\hline & $\begin{array}{l}\text { Temperature } \\
\left({ }^{\circ} \mathrm{C}\right)\end{array}$ & $\begin{array}{l}\text { Residence time } \\
(\mathrm{min})\end{array}$ & $\begin{array}{l}\text { Catalyst } \\
\text { type }\end{array}$ & Extractant & & & & \\
\hline \multirow[t]{4}{*}{ Nannochloropsis } & 400 & 240 & $\mathrm{Pt} / \mathrm{C}$ & DCM & NR & 2.24 & 43.0 & [78] \\
\hline & 400 & 240 & $\mathrm{Pt} / \mathrm{C}$ & DCM & 83 & 3.67 & 43.51 & [79] \\
\hline & 530 & 360 & $\mathrm{Pt} / \mathrm{C}$ & DCM & NR & 1.50 & 39.70 & [80] \\
\hline & 400 & 240 & HZSM-5 & DCM & 75 & 1.69 & 43.4 & [81] \\
\hline \multirow[t]{4}{*}{ Chlorella } & 400 & 60 & $\mathrm{Pt} / \gamma-\mathrm{Al}_{2} \mathrm{O}_{3}$ & $\mathrm{DCM}$ & 79.8 & 4.7 & 33.0 & [83] \\
\hline & 400 & 240 & $\mathrm{Ru} / \mathrm{C}+\mathrm{Ni}$ & DCM & 77.2 & 2.0 & 45.3 & [86] \\
\hline & 400 & 240 & $\stackrel{\mathrm{Ru} /}{\mathrm{C}}+\mathrm{Mo}_{2} \mathrm{C}$ & DCM & 51.5 & 2.87 & 43.30 & [84] \\
\hline & 400 & 240 & $\stackrel{\mathrm{Ru} /}{\mathrm{C}}+\mathrm{Mo}_{2} \mathrm{C}$ & DCM & 77.2 & 3.1 & 46.8 & {$[85]$} \\
\hline
\end{tabular}

$N R$ not reported

Table 3 Typical compositions of four most investigated algae strains

\begin{tabular}{|c|c|c|c|c|c|c|c|c|c|}
\hline \multirow[t]{2}{*}{ Algae } & \multicolumn{5}{|c|}{ Elemental composition (\%) } & \multicolumn{3}{|c|}{ Biochemical composition (\%) } & \multirow[t]{2}{*}{ References } \\
\hline & C & $\mathrm{H}$ & $\mathrm{O}$ & $\mathrm{N}$ & $\mathrm{S}$ & Carbohydrate & Lipid & Protein & \\
\hline \multirow[t]{4}{*}{ Nannochloropsis } & 43.3 & 6.0 & 25.1 & 6.4 & 0.5 & 12 & 28 & 52 & {$[45-47]$} \\
\hline & 57.8 & 8 & 25.7 & 8.6 & ND & 8 & 32 & 57 & {$[42,48]$} \\
\hline & 55.16 & 6.87 & 33.97 & 2.73 & 1.27 & 33 & 12 & 37 & [49] \\
\hline & 43.7 & 7.7 & 29.1 & 7.5 & 0.67 & 27.2 & 14.1 & 52.4 & {$[56]$} \\
\hline \multirow[t]{5}{*}{ Chlorella } & 52.6 & 7.1 & 32.2 & 8.2 & 0.5 & 9 & 25 & 55 & {$[42,48]$} \\
\hline & 51.4 & 6.6 & 30.9 & 11.1 & NR & 22 & 0.1 & 71.3 & {$[28,38,59]$} \\
\hline & 60.5 & 10.2 & 9.5 & 1.9 & 0.95 & 25.9 & 59.9 & 9.3 & [56] \\
\hline & 50.4 & 7.9 & 37.4 & 2.9 & 0.2 & 45.6 & 24.7 & 16.8 & {$[39,60]$} \\
\hline & 53.5 & 7.4 & 27.6 & 11.0 & 0.5 & 25 & 4 & 60 & [61] \\
\hline \multirow[t]{4}{*}{ Spirulina } & 45.2 & 6.4 & 37.8 & 9.8 & 0.80 & 20 & 5 & 64 & {$[62,63]$} \\
\hline & 42.96 & 8.49 & 39.19 & 8.87 & 0.49 & 22.4 & 8.2 & 69.4 & {$[29,57]$} \\
\hline & 42.26 & 5.86 & 47.26 & 3.47 & 1.15 & 19 & 6 & 60 & [49] \\
\hline & 53.7 & 7.7 & 25.9 & 12.1 & 0.6 & 11 & 8 & 68 & [61] \\
\hline Dunaliella & 39.0 & 5.4 & 53.0 & 2 & 0.6 & 21.7 & 2.9 & 61.3 & {$[66,68]$} \\
\hline
\end{tabular}

$N D$ not detected, $N R$ not reported

nitrogen into the aqueous phase as ammonia required a longer time.

Ross et al. [58] converted Spirulina to biocrude using alkali and organic acids. The biocrude yield followed the trend of sodium carbonate $>$ acetic acid $>$ potassium hydroxide $>$ formic acid. In addition to Ross, other researchers have studied the liquefaction of Spirulina [29, 57, 61-65]. The results from Huang et al. [29] proved that the addition of $\mathrm{FeS}$ was helpful in improving its yield and reducing the nitrogen content. Jazrawi et al. [61] implemented this liquefaction process at a continuous pilot-scale plant, and obtained a low biocrude yield with a nitrogen content of $3.3 \%$ and an $\mathrm{HHV}$ of $30.7 \mathrm{MJ} / \mathrm{kg}$ at a low reaction temperature of $250{ }^{\circ} \mathrm{C}$. These results indicate that most of the protein in the algae biomass might not be converted into biocrude. Yuan et al. [57] performed this experiment using different organic solvents. Compared with 1,4-dioxane, liquefaction in alcohols produced higher biocrude yields for the same reason as that in Zhang et al. [28]. Also, the use of methanol resulted in the lowest nitrogen content of $7.46 \%$ and the highest HHV of $39.83 \mathrm{MJ} / \mathrm{kg}$ when compared with those of ethanol and 1,4dioxane. The reduction of nitrogen fractions in biocrude was probably attributable to deamination reactions during liquefaction of the biomass, whereby methanol could act as a hydrogen-donor solvent and promote the formation of hydrogen-free radical and HDN reactions.

Zou et al. [66-68] converted Dunaliella tertiolecta into biocrude using a sodium carbonate catalyst. The authors found that the yield and nitrogen content of biocrude 
declined with the addition of the catalyst, while the HHV of the biocrude increased. Chen et al. [69] liquefied $D u$ naliella tertiolecta in an ethanol-water mixture, and reported that a maximum biocrude yield of $64.68 \%$ was achieved at $320{ }^{\circ} \mathrm{C}$ for 30 min with a $40 \%$ (v/v) ethanol solution. This biocrude contained $5.35 \%$ nitrogen, which is only a little higher than that in water.

Other algae strains have also been liquefied into biocrude [30, 34, 51, 53, 70-76]. Zhou et al. [72] used sodium carbonate as a catalyst to liquefy Enteromorpha prolifera into biocrude and obtained $5.76 \%$ nitrogen content at $300{ }^{\circ} \mathrm{C}$ for 30 min with a $5 \%$ catalyst solution. In contrast to Zou [68], the biocrude yield increased with the addition of the catalyst. Zhou et al. [30] also performed this same liquefaction experiment in methanol and ethanol and produced biocrude with a high nitrogen content of $7.71 \%$, which was later interpreted by Zhang et al. [28] and Chen et al. [69]. Compared with defatted Scenedesmus [63], biocrude with a higher yield and lower nitrogen content could be produced via the liquefaction of raw algae. Moreover, through a series of chemical processes such as transesterification, defatted algae was converted to green biodiesel. The shorter processing time, higher temperature, and sodium carbonate catalyst increased the biocrude yield from Microcystis viridis [73]. Sargassum patens [74] have also been liquefied into biocrude, yielding a nitrogen content of $2.45 \%$ under optimal conditions. This low nitrogen content was associated with an algae biomass whose nitrogen content was low. Torri et al. [34, 75] converted Desmodesmus into biocrude with a nitrogen content of $6.3 \%$ at a $375{ }^{\circ} \mathrm{C}$ reaction temperature and 5-min reaction time. For Laminaria saccharina [76], increasing the potassium hydroxide catalyst loading decreased the biocrude yield and nitrogen content, while a high temperature increased the biocrude yield and the
HHV, as well as decreased the nitrogen content. In addition, as revealed by mass spectrometry (MS) analysis $[52,55,56]$, biocrude was obtained by the HTL of algae comprising thousands of compounds, for which it is difficult to efficiently control denitrogenation.

\section{Upgrading Algae Biocrude}

Raw biocrude has a high nitrogen content that must be reduced to meet transportation fuel standards. Recently, Cole et al. [77] systematically investigated the hydrothermal upgrading of Oedogonium. The results of this study represents a major breakthrough in the field of algal biocrude, with its emphasis on reducing the nitrogen content of the algal biomass and at each step of the production process, as shown in Fig. 2. With the addition of $10 \mathrm{wt} \%$ heptane, non-polar biocrude components selectively accumulate in the organic phase with the result being that the biocrude (after separation from the co-solvent) has a much lower nitrogen content (up to $50 \%$ less) than polar biocrude, which remains in the aqueous phase. After a series of operations including vacuum distillation, mixing with feed green and catalytic hydrotreating, the macroalgae can be converted to a renewable, high-quality liquid hydrocarbon fuel.

Other publications addressed the upgrading of HTL biocrude [78-87]. Duan and Savage [78, 79] conducted catalytic upgrading of crude biocrude that had been produced via the HTL of Nannochloropsis under various conditions. The authors realized a maximum upgraded yield of $83 \%$ at $400{ }^{\circ} \mathrm{C}$ for 240 min with a $20 \% \mathrm{Pt} / \mathrm{C}$ catalyst. However, this upgraded biocrude still contained a high nitrogen content of $3.68 \%$. They also found that the transfer of nitrogen as ammonia into the aqueous phase was enhanced in a high-pressure hydrogen atmosphere. The

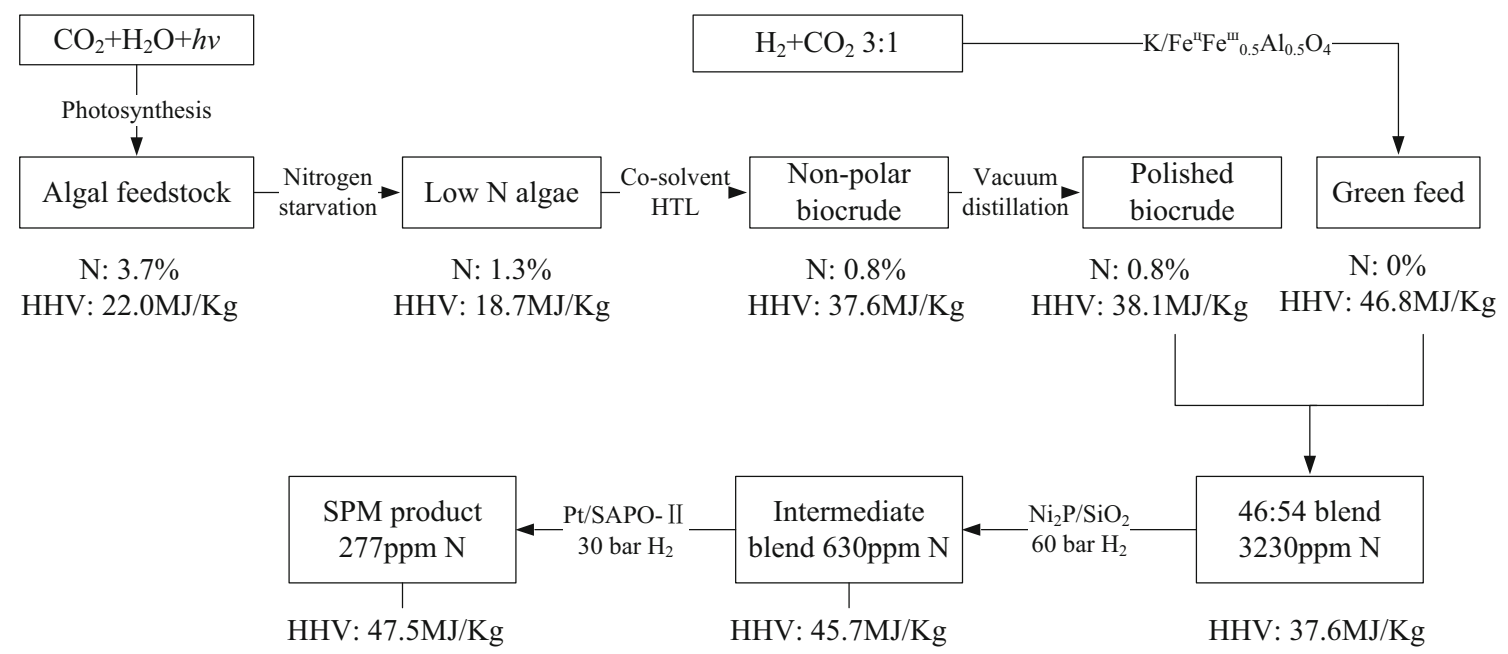

Fig. 2 Overview of each step in the conversion of Oedogonium into high-quality fuel [77] 
nitrogen content decreased as the amount of catalyst increased. In another paper by the same authors [80], upgraded biocrude with the lowest nitrogen content of $1.50 \%$ was achieved at $530{ }^{\circ} \mathrm{C}$ for 360 min with a $10 \% \mathrm{Pt} /$ $\mathrm{C}$ catalyst. Catalytic hydrotreatment was also effectively applied for the HDN of biocrude produced by the HTL of Nannochloropsis algae [88]. This upgrade process reduced the $4 \%$ nitrogen content to $<0.25 \%$. The effective reduction of nitrogen is particularly interesting as the level of nitrogen is much higher by this process than by typical petroleum hydrotreatment.

$\mathrm{Li}$ and Savage [81] carried out a similar upgrading process with an HZSM-5 catalyst in high-pressure hydrogen, and reported the production of upgraded biocrude with $1.69 \%$ nitrogen and $43.4 \mathrm{MJ} / \mathrm{kg} \mathrm{HHV}$. In addition, the investigation conducted by Patel et al. [82] demonstrated that denitrogenation can be achieved rapidly (in seconds) during the upgrading of algae paste, but requires more extreme reaction conditions.

Duan et al. [83] studied the upgrading of crude biocrude derived from Chlorella pyrenoidosa with a platinum catalyst supported on $\gamma-\mathrm{Al}_{2} \mathrm{O}_{3}$, which produced a maximum upgraded biocrude yield of $79.8 \%$ with a nitrogen content of $4.7 \%$. This maximum yield might be caused by the reaction between the crude biocrude and formic acid. In general, the nitrogen content in biocrude decreased after upgrading, but this reduced nitrogen content is still above the required threshold of transportation fuel. In another paper [84], the authors compared different biocrude production methods from Chlorella pyrenoidosa, including HTL, Al (alcoholysis), Py (pyrolysis), and HPy (hydropyrolysis), and the catalytic hydrothermal upgrading of crude biocrude produced by these four conversion routes. Upgraded biocrude was obtained at $400{ }^{\circ} \mathrm{C}$ for $4 \mathrm{~h}$ with a $10 \mathrm{wt} \%\left(\mathrm{Ru} / \mathrm{C}+\mathrm{Mo}_{2} / \mathrm{C}\right)$ catalyst. The results showed that the nitrogen content was reduced from 7.05 to $2.87 \%$ by upgrading and the HHV increased to 43.30 from $37.42 \mathrm{MJ} /$ $\mathrm{kg}$, which further confirms that the properties of biocrude are seriously influenced by the reaction routes. $\mathrm{Xu}$ et al. [85] investigated the catalytic upgrading of pretreated algal biocrude with two-component catalysts and obtained a maximum upgraded biocrude of $77.2 \%$ with an $\mathrm{HHV}$ of $46.8 \mathrm{MJ} / \mathrm{kg}$ with $\mathrm{Ru} / \mathrm{C}+\mathrm{Mo}_{2} \mathrm{C}$. However, the nitrogen content of this upgraded biocrude was highest at $3.1 \%$. Interestingly, the best denitrogenation result was achieved using the residue as the catalyst after upgrading. Bai et al. [86] developed a two-step process to upgrade the same crude biocrude. First, they pretreated the crude biocrude at $350{ }^{\circ} \mathrm{C}$ for $240 \mathrm{~min}$ in a hydrogen atmosphere and then upgraded the pretreated biocrude at $400{ }^{\circ} \mathrm{C}$ with various catalysts. The results showed that pretreatment can decrease the nitrogen content from $8.0 \%$ in crude biocrude to $4.1 \%$ in pretreated biocrude, and Raney-Ni generated the best denitrogenation performance. The report showed that both $\mathrm{Ru} / \mathrm{C}$ and Raney-Ni combined with upgraded biocrude can obtain good denitrogenation results, with a maximum biocrude yield of $77.2 \%$, nitrogen content of $2.0 \%$, and HHV of $45.3 \mathrm{MJ} / \mathrm{kg}$, which could be attributed to the bimetallic synergy effect.

\section{Summary}

Previous studies have indicated that algae strains and liquefaction conditions can affect the properties of biocrude. As yet, the extent to which the nitrogen content of biocrude is related to algae types is open to question. Therefore, understanding protein behavior and its contribution to the properties of biocrude is vital, as algal biomasses having similar biochemical compositions give different product yields. Liquefaction with water generates nitrogen in the form of ammonia transferred to the aqueous phase, and liquefaction with alcohol can improve biocrude yield due to the reaction between alcohol and the biomass. However, it is difficult for liquefaction with alcohol to reduce the nitrogen content in biocrude. The limited residence time may increase biocrude's nitrogen content because transferring organic nitrogen into the aqueous phase likely requires a much longer time. In addition, a high liquefaction temperature can convert more proteins into biocrude, which also results in high-energy consumption problems and high biocrude nitrogen content. In conclusion, developing appropriate methods to improve biocrude yield and its characteristics is particularly important.

To improve the quality of biocrude, one route has received much attention and has been widely used in this field-catalytic hydrotreatment processing with homogeneous catalysts such as alkali catalysts or organic acids, and heterogeneous catalysts such as zeolite or supported metal catalysts. Some previous attempts to upgrade biocrude have shown only limited success, and the direct use of upgraded biocrude as transportation fuel remains unacceptable due to the significant amount of nitrogen oxides that would be released to the environment during combustion, thus causing air pollution. As such, the denitrogenation of algae biocrude requires further research.

\section{Removal of Nitrogen from Biocrude}

To produce a nitrogen-depleted biomass of Oedogonium for conversion to biocrude through HTL, the biomass was cultured in dechlorinated water without the addition of nutrients for seven days [77], as shown in Fig. 2. Research has shown that biomass nitrogen content was significantly reduced using the method of nutrient starvation. Such reduction is especially attractive because it is achieved 
without the need for additional chemicals or complex processes. Nutrient starvation was also studied by Neveux et al. [89], which led to a reduction in the nitrogen content of $51-59 \%$. The authors also analyzed the effect of washing the biomass on the quality and quantity of biocrude produced. Experimental results show that nutrient starvation of the cultures and washing of the biomass, either individually or combined, significantly affected the quality of the macroalgal feedstocks, and consequently, improved the quality of biocrude. Unfortunately, the yield and HHV of this biocrude is reduced by the lack of nutrients. While these pathways have a long way to go before producing satisfactory results, successful denitrogenation methods in the chemical engineering field may be forthcoming. Methods currently being explored include the adsorptive and extractive denitrogenations of fossil fuel and the HDN of the main nitrogen compounds, which are summarized in Table 4. These main compounds comprise aliphatic and cyclic compounds, including amides, nitriles, indoles, pyridines, pyrroles, pyrrolidines, pyrrolidinones, piperidines, carbazoles, pyrazines, and quinoline.

\section{HDN of Main Nitrogen Compounds in Biocrude}

Small-molecule aliphatic nitrogen compounds can be dissolved in water, while the remaining macromolecules remain in the biocrude. For these compounds, such as palmitamide, hexadecanenitrile and stearonitrile, HDN is an effectual means for converting them into hydrocarbons [90-92]. However, the rupture of $\mathrm{C}-\mathrm{N}$ bond-breaking rings is very difficult to achieve in aromatic nitrogen compounds even under drastic conditions. Therefore, we investigated the HDN of these compounds with various catalysts, focusing primarily on the HDN of quinoline, which we selected as the model compound.

It is well documented that some phosphides exhibit catalytic activity in the $\mathrm{HDN}$ of quinoline, such as $\mathrm{Ni}_{2} \mathrm{P}$ [93, 94], MoP [95], and Ni-rich bimetallic phosphides [96, 97], which were typically modified with a metallic oxide, such as $\mathrm{TiO}_{2}$ and $\mathrm{CeO}_{2}$. $\mathrm{HDN}$ is performed at high temperatures and high pressures with these catalysts and an abundance of the desired product propylcyclohexane has been produced. Unfortunately, some nitrogen compounds, like tetrahydroquinoline, have also appeared giving rise to further denitrogenation requirements.

Metallic oxides like $\mathrm{MoO}_{3}$ and $\mathrm{NiO}[98,99]$ have been used to catalyze the $\mathrm{HDN}$ of quinoline, and $\mathrm{MoO}_{3}$ exhibited a synergetic effect with $\mathrm{NiO}$ in this process. In contrast to phosphides, the abundant product was propylbenzene, but some quinoline hydrides were retained in the hydrocarbons. The HDN of quinoline was also conducted with $\mathrm{Pt} / \mathrm{NaY}$ and $\mathrm{PtMo} / \mathrm{NaY}$ catalysts [100], but only about $35 \%$ of the quinoline was converted, and propylcyclohexane and propylbenzene were produced with both catalysts.

Phosphide WP was employed in the HDN of pyridine [101]. Regrettably, not only was the conversion lower than $20 \%$, but it also produced a great quantity of piperidine in the process. We can infer that phosphide shows better catalytic activity in the HDN of quinoline than pyridine although pentane was produced with a selectivity of $37.1 \%$ via the latter's HDN. Hydrothermal HDN of pyridine was performed using various catalysts [102], and we found $\mathrm{Pt} /$ $\gamma-\mathrm{Al}_{2} \mathrm{O}_{3}$ to be the most active catalyst, achieving almost complete conversion under proper conditions. In these tests, its major products were butane and pentane as well as small amounts of methane, ethane, and propane. Deng et al. [103] reported the HDN pathway of pyridine with MoP (0 1 0 ), that is, the route pyridine $\rightarrow$ 4-monohypyridine $\rightarrow 3,4$ dihydropyridine $\rightarrow$ 1,3,4-trihydropyridine $\rightarrow$ 1,3,4,5-tetrahydropyridine $\rightarrow \mathrm{CH}\left(\mathrm{CH}_{2}\right)_{3} \mathrm{CHNH}$, followed by $\mathrm{C}-\mathrm{N}$ bond rupture, and then $\mathrm{NH}_{3}$ generation.

The $\mathrm{HDN}$ of piperidines was studied with $\mathrm{Ni}_{2} \mathrm{P} / \mathrm{SiO}_{2}$ and $\mathrm{Ni}-\mathrm{Mo}-\mathrm{S} / \mathrm{Al}_{2} \mathrm{O}_{3}$ catalysts [104], which yielded main products of hexane and 2-hexene. A high conversion of piperidines also appeared at high temperature with both catalysts. Given the piperidine produced from the HDN of pyridine with the WP catalyst, the combination of WP and $\mathrm{Ni}_{2} \mathrm{P}$ catalysts might yield better performance in the HDN of pyridine.

The HDN of carbazole was performed with the phosphides $\mathrm{Ni}_{0.07} \mathrm{MoP}$ [105] and $\mathrm{NiB}$ alloy [106], whose main product was bicyclohexane. The HDN of carbazole and light gas oil with supported $\mathrm{Ni}_{x} \mathrm{MoP}$ catalysts were also investigated [107], and we found the highest conversion rate of carbazole and highest selectivity of bicyclohexane were obtained with $\mathrm{Ni}_{0.3} \mathrm{MoP} / \mathrm{Al}_{2} \mathrm{O}_{3}$, as well as the highest activity for the HDN of light gas oil.

This method consumes large amounts of hydrogen, and to achieve an ideal denitrification effect, in-depth hydrogenation is required, which leads to harsh reaction conditions (2.0-5.0 MPa, 300-500 $\left.{ }^{\circ} \mathrm{C}\right)$ [108]. The input-output ratio of the energy production process greatly increases if we take into account the investment made in the purchase of hydrogen or hydrogen production and the energy consumption of the high-pressure reaction. Thus, finding new methods to achieve non-hydrogenation $\mathrm{C}-\mathrm{N}$ bond rupture is important.

\section{Adsorptive and Extractive Denitrogenations of Biocrude}

In comparison to HDN, adsorptive and extractive denitrogenations have been researched extensively for the desulfurization and denitrogenation of petroleum to derive transportation fuel. There have been a number of recent 
Table 4 Main nitrogen compounds produced from HTL of algae

\begin{tabular}{|c|c|c|c|}
\hline Type & Compound & Chemical formula & References \\
\hline Amides & Palmitamide & $\mathrm{C}_{16} \mathrm{H}_{33} \mathrm{NO}$ & {$[45-47]$} \\
\hline \multirow[t]{3}{*}{ Nitriles } & Hexadecanenitrile & $\mathrm{C}_{16} \mathrm{H}_{31} \mathrm{~N}$ & {$[28,29]$} \\
\hline & Stearonitrile & $\mathrm{C}_{18} \mathrm{H}_{35} \mathrm{~N}$ & {$[57]$} \\
\hline & 2,4,6-Trimethyl-benzonitrile & $\mathrm{C}_{10} \mathrm{H}_{11} \mathrm{~N}$ & {$[57,62]$} \\
\hline \multirow[t]{9}{*}{ Indoles } & Indole & $\mathrm{C}_{8} \mathrm{H}_{7} \mathrm{~N}$ & {$[45,46]$} \\
\hline & 1-Methyl-indole & $\mathrm{C}_{9} \mathrm{H}_{9} \mathrm{~N}$ & [58] \\
\hline & 2-Methyl-indole & $\mathrm{C}_{9} \mathrm{H}_{9} \mathrm{~N}$ & {$[72]$} \\
\hline & 3-Methyl-indole & $\mathrm{C}_{9} \mathrm{H}_{9} \mathrm{~N}$ & {$[57]$} \\
\hline & 6-Methyl-indole & $\mathrm{C}_{9} \mathrm{H}_{9} \mathrm{~N}$ & {$[46]$} \\
\hline & 7-Methyl-indole & $\mathrm{C}_{9} \mathrm{H}_{9} \mathrm{~N}$ & [45] \\
\hline & 5,7-Dimethyl-indole & $\mathrm{C}_{10} \mathrm{H}_{11} \mathrm{~N}$ & [57] \\
\hline & 5,6,7-Trimethyl-indole & $\mathrm{C}_{11} \mathrm{H}_{13} \mathrm{~N}$ & {$[57,74]$} \\
\hline & 2,3,7-Trimethyl-indole & $\mathrm{C}_{11} \mathrm{H}_{13} \mathrm{~N}$ & [74] \\
\hline Pyridines & 5-Ethyl-2-methyl-pyridine & $\mathrm{C}_{8} \mathrm{H}_{11} \mathrm{~N}$ & [57] \\
\hline \multirow[t]{6}{*}{ Pyrroles } & 1-Methyl-pyrrole & $\mathrm{C}_{5} \mathrm{H}_{7} \mathrm{~N}$ & [47] \\
\hline & 1-Ethyl-pyrrole & $\mathrm{C}_{6} \mathrm{H}_{9} \mathrm{~N}$ & [47] \\
\hline & 2,5-Dimethylpyrrole & $\mathrm{C}_{6} \mathrm{H}_{9} \mathrm{~N}$ & {$[47]$} \\
\hline & 3-Ethyl-5-methylpyrrole & $\mathrm{C}_{7} \mathrm{H}_{11} \mathrm{~N}$ & [29] \\
\hline & 2-Ethyl-3,5-dimethylpyrrole & $\mathrm{C}_{8} \mathrm{H}_{13} \mathrm{~N}$ & {$[57]$} \\
\hline & 3-Ethyl-2,4,5-trimethylpyrrole & $\mathrm{C}_{9} \mathrm{H}_{15} \mathrm{~N}$ & {$[28]$} \\
\hline \multirow[t]{5}{*}{ Pyrrolidines } & 1-Butyl-pyrrolidine & $\mathrm{C}_{8} \mathrm{H}_{17} \mathrm{~N}$ & [58] \\
\hline & 1-Stearoyl-pyrrolidine & $\mathrm{C}_{22} \mathrm{H}_{41} \mathrm{~N}$ & {$[67,68]$} \\
\hline & 1-Ethyl-2-pyrrolidinone & $\mathrm{C}_{6} \mathrm{H}_{11} \mathrm{NO}$ & {$[45,46]$} \\
\hline & 1-Butyl-2-pyrrolidinone & $\mathrm{C}_{8} \mathrm{H}_{15} \mathrm{NO}$ & [58] \\
\hline & 1-Propyl-2,5-pyrrolidinedione & $\mathrm{C}_{7} \mathrm{H}_{11} \mathrm{NO}_{2}$ & [62] \\
\hline \multirow[t]{4}{*}{ Piperidines } & 1-Methyl-piperidine & $\mathrm{C}_{6} \mathrm{H}_{13} \mathrm{~N}$ & [46] \\
\hline & 1-Pentyl-piperidine & $\mathrm{C}_{10} \mathrm{H}_{21} \mathrm{~N}$ & [58] \\
\hline & Piperidine-2,5-dione & $\mathrm{C}_{5} \mathrm{H}_{7} \mathrm{NO}_{2}$ & [58] \\
\hline & 2,2,6,6-Tetramethyl-4-piperidone & $\mathrm{C}_{9} \mathrm{H}_{15} \mathrm{NO}_{3}$ & [28] \\
\hline Carbazoles & Carbazole & $\mathrm{C}_{12} \mathrm{H}_{9} \mathrm{~N}$ & [45] \\
\hline \multirow[t]{3}{*}{ Pyrazines } & 2-Methylpyrazine & $\mathrm{C}_{5} \mathrm{H}_{6} \mathrm{~N}_{2}$ & {$[30]$} \\
\hline & 2,5-Dimethylpyrazine & $\mathrm{C}_{6} \mathrm{H}_{8} \mathrm{~N}_{2}$ & [72] \\
\hline & 3-Ethyl-2,5-dimethylpyrazine & $\mathrm{C}_{8} \mathrm{H}_{12} \mathrm{~N}_{2}$ & [72] \\
\hline \multirow[t]{2}{*}{ Quinolines } & Quinoline & $\mathrm{C}_{9} \mathrm{H}_{7} \mathrm{~N}$ & {$[45,72]$} \\
\hline & 4-Methylquinoline & $\mathrm{C}_{10} \mathrm{H}_{9} \mathrm{~N}$ & [72] \\
\hline
\end{tabular}

studies on the denitrogenation of model fuel [109-111] and light cycle oil [112, 113]. Unlike HDN, adsorptive and extractive denitrogenations have been mainly employed to remove aromatic nitrogen compounds.

The silica-zirconia co-gel adsorbent was shown to have a high capacity for selectively adsorbing nitrogen compounds from light gas oil at mild temperature and ambient pressure [114]. Moreover, the adsorption capacity of the adsorbent can be more fully recovered by regeneration carried out in methyl isobutyl ketone and methyl tertiary butyl ether.

Lithium-modified mesoporous silica adsorbent displayed a very strong adsorption affinity for nitrogen compounds [115] and about $40 \%$ of the nitrogen compounds were removed under appropriate conditions. The adsorbent can be easily regenerated using methyl isobutyl ketone at a roughly constant readsorption capacity.

Heterogeneous cross-linking was also reported [116], in which the macroporous polymer poly (glycidyl methacrylate) was employed as the hydrophilic support coupled with tetranitrofluorenone to selectively remove neutral nitrogen compounds from heavy gas oil, and $6.7 \%$ of the nitrogen species were successfully removed. Reuse of this polymer showed consistency in the selective removal of nitrogen compounds, with a continuous and unchanging removal rate. 
Some commercially available ion-exchange resins bearing pyridinium chloride functionality have exhibited much higher adsorptive capacity and selectivity for neutral nitrogen compounds [117]. The nitrogen concentration was greatly reduced in model fuel (dodecane-toluene mixture) and heavy gas oil. Regeneration of this sorbent is easily achieved using polar organic solvents like methanol.

Iron-nanoparticle-modified activated carbon was employed to remove nitrogen compounds (indoline and quinoline) in model diesel (mixture of decane and hexadecane containing sulfur compounds) [118]. This adsorbent demonstrates better affinity for indoline than quinoline.

Mesoporous molecular sieves (Ti-HMS, HMS, and MCM-41) have shown perfect performance in the adsorptive denitrogenation of model fuel (octane containing pyridine, quinoline, pyrrole, and indole) and commercial diesel [119, 120]. HMS and Ti-HMS exhibited higher adsorbability to indole, whereas MCM-41 showed better affinity with indole and quinoline. The adsorbent is easily regenerated by washing many times with ethanol and its performance may be maintained.

The metal organic framework (MOF) MIL-101 has long been used to remove nitrogen compounds from model fuel [121-123]. Although virgin MOFs have unsatisfactory properties, MOFs modified with ethylenediamine, phosphotungstic acid, or other compounds have exhibited remarkable performance. Modified MOFs, while promoting the adsorption of quinoline, have little influence on the adsorption of indole. In addition, they have exhibited good regenerative capacity when washed with acetone or ethanol, but adsorption capacity declines after a number of regeneration cycles.

Recently, Chen et al. [124] reported an extraction method for removing the nitrogen heterocyclic in algal biocrude using water as a solvent. This method is green, safe, and easily implemented, and the results show that nitrogen content in algal biocrude decreases from 6.83 to $5.75 \%$ with improved carbon and hydrogen contents. However, the authors also found that the nitrogen content remained too high to meet the requirements of the transportation fuel. The authors also discussed the potential for extracting protein from algae feedstocks prior to the conversion of the residual biomass to biocrude [125]. This is an interesting option for reducing nitrogen in algae and generating multiple products from a single feedstock.

The extractive denitrogenation of fossil fuel was widely researched using various ionic liquids [126-128]. Aromatic nitrogen compounds were more easily extracted than aromatic hydrocarbons when using ionic liquids. The solubilities of nitrogen compounds vary with the ionic liquids. Water dilution is used to regenerate ionic liquids and the extraction efficiency after a number of regeneration cycles are nearly identical to those in the first cycle. In another study, researchers prepared supported liquid membranes using ionic liquids to separate organic nitrogen compounds from model fuel (heptane mixtures) at room temperature [129]. These organic nitrogen compounds (quinoline, isoquinoline, and pyridine) were more permeable than heptane, thus resulting in the purification of the fuel.

A new approach is needed to address this problem. For instance, nitrogenous substances that are harmful in biocrude could be used as raw materials for the pharmaceutical industry. Amino acids, as an intermediate product in the HTL of algae, have high commercial value (for use in feed, food, pharmaceuticals, and cosmetics) compared with most other biomass fractions. Some researchers [130, 131] have explored the potential of hydrothermal technologies for extracting amino acids from various protein-rich feedstocks. If the HTL reaction can be controlled, amino acids can be extracted during the process, thus making it possible to not only effectively utilizes the protein in algae, but also to reduce the nitrogen content of the biocrude. This process is in the early stages and needs further research.

\section{Summary}

To improve the quality of biocrude by achieving lower nitrogen content, the cultivation of algae by starvation has been researched and has achieved tremendous results in reducing the hydrogen requirement for biocrude upgrading into a blendable fuel. Generally, the HDN of the main nitrogen compounds in fossil fuel has been conducted using pure substances and model fuel. Some impressive results have been achieved in appropriate conditions. However, given the complicated composition of biocrude, i.e., unsaturated compounds and moisture, the performance of these catalysts is still unknown with respect to the HDN of biocrude. Investigations are also needed regarding the deactivation properties and reusability of these catalysts.

Adsorptive and extractive denitrogenations have been carried out on biocrude, model oil, and fossil fuel, but mainly to achieve the further denitrogenation of fossil fuel, which contains nitrogen content at ppm levels. Aromatic hydrocarbons can also be adsorbed or extracted by some adsorbents and extraction agents, resulting in reduced biocrude yield. In addition, each nitrogen atom may be linked several or even dozens of times to carbon and hydrogen atoms, so after separation the remnant materials are very limited. Apart from fuel, biocrude can also be treated as feedstock for bulk chemicals. Cracking and catalytic pyrolysis methods were shown to be significant treatments for the utilization of biocrude [132]. 


\section{Conclusions and Outlook}

Based on extensive work in this field, the HTL of algae has been determined to be a very promising process for producing biocrude. Nevertheless, the associated high nitrogen content impedes its widespread adoption in the realm of transportation. Although the upgrading of algae biocrude has made some definite improvements, the direct use of these upgraded biocrudes in transportation remains unacceptable as yet. The HDN of nitrogen compounds retains some hydrogenated hydrocarbon in biocrude, as compared with adsorptive and extractive denitrogenations, while the harsh treatment condition impeded HDN's popularity. Also, the most active catalyst identified for the HDN of model compounds does not appear to have the best performance in denitrifying algal biocrude. Adsorptive and extractive denitrogenations can remove nitrogen compounds; however, their use likely results in a significant loss of biocrude yield. Moreover, adsorptive and extractive denitrogenations are usually performed in ultralow nitrogen content conditions.

In the near future, research attention should be focused on the following issues: (1) the selection of the appropriate catalysts and solvents to better control product distribution and to improve the properties of biocrude. The combination of two catalysts has been shown to perform better than either catalyst alone, which suggests that denitrogenation with two or more catalysts may be a productive avenue for further research; (2) the complex composition of algal biocrude often occurs in the presence of various components of a nitric heterocyclic compound, thus the denitrogenation mechanisms used on several model compounds cannot be used in biocrude in all cases. Therefore, it will be necessary to study dynamic behaviors to reap the desired product; (3) there are some disadvantages to the above-mentioned denitrification methods, such as the high-energy consumption of HDN and the poor selectivity of adsorptive and extractive denitrogenations. An optimal combination of chemical and physical denitrogenations may be more effective in generating biocrude that meets the needs of transport fuels without significantly reducing yield.

Acknowledgements This work was supported by Innovation Foundation of Tianjin University (2016XZC-0028).

Open Access This article is distributed under the terms of the Creative Commons Attribution 4.0 International License (http://crea tivecommons.org/licenses/by/4.0/), which permits unrestricted use, distribution, and reproduction in any medium, provided you give appropriate credit to the original author(s) and the source, provide a link to the Creative Commons license, and indicate if changes were made.

\section{References}

1. Ragauskas AJ, Williams CK, Davison BH et al (2006) The path forward for biofuels and biomaterials. Science 311(5760):484-489

2. Khan SA, Rashmi Hussain MZ et al (2009) Prospects of biodiesel production from microalgae in India. Renew Sustain Energy Rev 13(9):2361-2372

3. Cuellar-Bermudez SP, Garcia-Perez JS, Rittmann BE et al (2014) Photosynthetic bioenergy utilizing $\mathrm{CO}_{2}$ : an approach on flue gases utilization for third generation biofuels. J Clean Product 98:53-65

4. Tsukahara K, Sawayama S (2005) Liquid fuel production using microalgae. J Jpn Petrol Inst 48(5):251-259

5. Chen CY, Yeh KL, Aisyah R et al (2011) Cultivation, photobioreactor design and harvesting of microalgae for biodiesel production: a critical review. Bioresour Technol 102(1):71-81

6. Harun R, Danquah MK, Forde GM (2009) Microalgal biomass as a fermentation feedstock for bioethanol production. J Chem Technol Biotechnol 85(2):199-203

7. John RP, Anisha GS, Nampoothiri KM et al (2011) Micro and macroalgal biomass: a renewable source for bioethanol. Bioresour Technol 102(1):186-193

8. Johnson MB, Wen ZY (2009) Production of biodiesel fuel from the microalga Schizochytrium limacinum by direct transesterification of algal biomass. Energy Fuels 23(10):5179-5183

9. Levine RB, Pinnarat T, Savage PE (2010) Biodiesel production from wet algal biomass through in situ lipid hydrolysis and supercritical transesterification. Energy Fuels 24(9):5235-5243

10. Miao XL, Wu QY, Yang CY (2004) Fast pyrolysis of microalgae to produce renewable fuels. J Anal Appl Pyrol 71(2):855-863

11. Grierson S, Strezov V, Ellem G et al (2009) Thermal characterisation of microalgae under slow pyrolysis conditions. J Anal Appl Pyrol 85(1/2):118-123

12. Pan P, Hu CW, Yang WY et al (2010) The direct pyrolysis and catalytic pyrolysis of Nannochloropsis sp. residue for renewable bio-oils. Bioresour Technol 101(12):4593-4599

13. Chang ZF, Duan PG, Xu YP (2015) Catalytic hydropyrolysis of microalgae: influence of operating variables on the formation and composition of bio-oil. Bioresour Technol 184:349-354

14. Chakinala AG, Brilman DWF, van Swaaij WPM et al (2010) Catalytic and non-catalytic supercritical water gasification of microalgae and glycerol. Ind Eng Chem Res 49(3):1113-1122

15. Guan Q, Savage PE, Wei C (2012) Gasification of alga Nannochloropsis sp. in supercritical water. J Supercrit Fluids 61:139-145

16. Valdez PJ, Nelson MC, Wang HY et al (2012) Hydrothermal liquefaction of Nannochloropsis sp.: systematic study of process variables and analysis of the product fractions. Biomass Bioenerg 46:317-331

17. Roberts GW, Fortier MOP, Sturm BSM et al (2013) Promising pathway for algal biofuels through wastewater cultivation and hydrothermal conversion. Energy Fuels 27(2):857-867

18. Roussis SG, Cranford R, Sytkovetskiy N (2012) Thermal treatment of crude algae oils prepared under hydrothermal extraction conditions. Energy Fuels 26(8):5294-5299

19. Toor SS, Rosendahl LA, Hoffmann J et al (2014) Hydrothermal liquefaction of biomass. Br J Nurs 10(21):189-217

20. Heilmann SM, Davis HT, Jader LR et al (2010) Hydrothermal carbonization of microalgae. Biomass Bioenerg 34(6):875-882

21. Heilmann SM, Jader LR, Harned LA et al (2011) Hydrothermal carbonization of microalgae II. Fatty acid, char, and algal nutrient products. Appl Energy 88(10):3286-3290 
22. Kanaujia PK, Sharma YK, Garg MO et al (2014) Review of analytical strategies in the production and upgrading of bio-oils derived from lignocellulosic biomass. J Anal Appl Pyrol 105:55-74

23. Dote Y, Sawayama S, Inoue S et al (1994) Recovery of liquid fuel from hydrocarbon-rich microalgae by thermochemical liquefaction. Fuel 73(12):1855-1857

24. Minowa T, Yokoyama SY, Kishimoto M et al (1995) Oil production from algal cells of Dunaliella tertiolecta by direct thermochemical liquefaction. Fuel 74(12):1735-1738

25. Matsui TO, Nishihara A, Ueda C et al (1997) Liquefaction of micro-algae with iron catalyst. Fuel 76(11):1043-1048

26. Ikenaga N, Ueda C, Matsui T et al (2001) Co-liquefaction of micro algae with coal using coal liquefaction catalysts. Energy Fuels 15(2):350-355

27. Yang RL, Yu C, Wu YL et al (2013) Production of liquid fuel via coliquefaction of coal and Dunaliella tertiolecta in a sub-/supercritical water-ethanol system. Energy Fuels 27(5):2619-2627

28. Zhang JX, Chen WT, Zhang P et al (2013) Hydrothermal liquefaction of Chlorella pyrenoidosa in sub- and supercritical ethanol with heterogeneous catalysts. Bioresour Technol 133:389-397

29. Huang HJ, Yuan XZ, Zeng GM et al (2011) Thermochemical liquefaction characteristics of microalgae in sub- and supercritical ethanol. Fuel Process Technol 92(1):147-153

30. Zhou D, Zhang SC, Fu HB et al (2012) Liquefaction of macroalgae enteromorpha prolifera in sub-/supercritical alcohols: direct production of ester compounds. Energy Fuels 26(4):2342-2351

31. Yang WC, Li XG, Li ZH et al (2015) Understanding low-lipid algae hydrothermal liquefaction characteristics and pathways through hydrothermal liquefaction of algal major components: crude polysaccharides, crude proteins and their binary mixtures. Bioresour Technol 196:99-108

32. Toor SS, Rosendahl L, Rudolf A (2011) Hydrothermal liquefaction of biomass: a review of subcritical water technologies. Energy 36(5):2328-2342

33. Tian CY, Li BM, Liu ZD et al (2014) Hydrothermal liquefaction for algal biorefinery: a critical review. Renew Sustain Energy Rev 38:933-950

34. Torri C, Alba LG, Samori C et al (2012) Hydrothermal treatment (HTT) of microalgae: detailed molecular characterization of HTT oil in view of HTT mechanism elucidation. Energy Fuels 26(1):658-671

35. Peterson AA, Vogel F, Lachance RP et al (2008) Thermochemical biofuel production in hydrothermal media: a review of sub- and supercritical water technologies. Energy Environ Sci 1(1):32-65

36. Guo Y, Yeh T, Song WH et al (2015) A review of bio-oil production from hydrothermal liquefaction of algae. Renew Sustain Energy Rev 48:776-790

37. Jazrawi C, Biller P, He YY et al (2015) Two-stage hydrothermal liquefaction of a high-protein microalga. Algal Res 8:15-22

38. Yu G, Zhang YH, Schideman L et al (2011) Distributions of carbon and nitrogen in the products from hydrothermal liquefaction of low-lipid microalgae. Energy Environ Sci 4(11):4587-4595

39. Chakraborty M, Miao C, Mcdonald A et al (2012) Concomitant extraction of bio-oil and value added polysaccharides from Chlorella sorokiniana using a unique sequential hydrothermal extraction technology. Fuel 95(1):63-70

40. Barreiro DL, Prins W, Ronsse F et al (2013) Hydrothermal liquefaction (HTL) of microalgae for biofuel production: state of the art review and future prospects. Biomass Bioenerg $53: 113-127$
41. Gai C, Zhang YH, Chen WT et al (2015) An investigation of reaction pathways of hydrothermal liquefaction using Chlorella pyrenoidosa and Spirulina platensis. Energy Convers Manage 96:330-339

42. Biller P, Ross AB (2011) Potential yields and properties of oil from the hydrothermal liquefaction of microalgae with different biochemical content. Bioresour Technol 102(1):215-225

43. Neveux N, Yuen AKL, Jazrawi C et al (2014) Biocrude yield and productivity from the hydrothermal liquefaction of marine and freshwater green macroalgae. Bioresour Technol 155:334-341

44. Lopez Barreiro D, Zamalloa C, Boon N et al (2013) Influence of strain-specific parameters on hydrothermal liquefaction of microalgae. Bioresour Technol 146:463-471

45. Brown TM, Duan P, Savage PE (2010) Hydrothermal liquefaction and gasification of Nannochloropsis sp. Energy Fuels 24(6):3639-3646

46. Duan PG, Savage PE (2011) Hydrothermal liquefaction of a microalgae with heterogeneous catalysts. Ind Eng Chem Res 50(1):52-61

47. Valdez PJ, Dickinson JG, Savage PE (2011) Characterization of product fractions from hydrothermal liquefaction of Nannochloropsis sp. and the influence of solvents. Energy Fuels 25(7):3235-3243

48. Biller P, Riley R, Ross AB (2011) Catalytic hydrothermal processing of microalgae: decomposition and upgrading of lipids. Bioresour Technol 102(7):4841-4848

49. Toor SS, Reddy H, Deng S et al (2013) Hydrothermal liquefaction of Spirulina and Nannochloropsis salina under subcritical and supercritical water conditions. Bioresour Technol 131:413-419

50. Faeth JL, Valdez PJ, Savage PE (2013) Fast hydrothermal liquefaction of Nannochloropsis sp. to produce biocrude. Energy Fuels 27(3):1391-1398

51. Yoo G, Min SP, Yang JW et al (2015) Lipid content in microalgae determines the quality of biocrude and energy return on investment of hydrothermal liquefaction. Appl Energy 156:354-361

52. Sanguineti MM, Hourani N, Witt M et al (2015) Analysis of impact of temperature and saltwater on Nannochloropsis salina bio-oil production by ultra high resolution APCI FT-ICR MS. Algal Res 9:227-235

53. Valdez PJ, Tocco VJ, Savage PE (2014) A general kinetic model for the hydrothermal liquefaction of microalgae. Bioresour Technol 163:123-127

54. Li HY, Hu J, Zhang ZJ et al (2014) Insight into the effect of hydrogenation on efficiency of hydrothermal liquefaction and physico-chemical properties of biocrude oil. Bioresour Technol 163:143-151

55. Sudasinghe N, Dungan B, Lammers P et al (2014) High resolution FT-ICR mass spectral analysis of bio-oil and residual water soluble organics produced by hydrothermal liquefaction of the marine microalga Nannochloropsis salina. Fuel 119:47-56

56. Li H, Liu ZD, Zhang YH et al (2013) Conversion efficiency and oil quality of low-lipid high-protein and high-lipid low-protein microalgae via hydrothermal liquefaction. Bioresour Technol 154:322-329

57. Yuan XZ, Wang JY, Zeng GM et al (2011) Comparative studies of thermochemical liquefaction characteristics of microalgae using different organic solvents. Energy 36(11):6406-6412

58. Ross AB, Biller P, Kubacki ML et al (2010) Hydrothermal processing of microalgae using alkali and organic acids. Fuel 89(9):2234-2243

59. Yu G, Zhang Y, Schideman L et al (2011) Hydrothermal liquefaction of low lipid content microalgae into bio-crude oil. Trans Asabe 54(1):239-246 
60. MiaoC Chakraborty M, Chen SL (2012) Impact of reaction conditions on the simultaneous production of polysaccharides and bio-oil from heterotrophically grown Chlorella sorokiniana by a unique sequential hydrothermal liquefaction process. Bioresour Technol 110:617-627

61. Jazrawi C, Biller P, Ross AB et al (2013) Pilot plant testing of continuous hydrothermal liquefaction of microalgae. Algal Res 2(3):268-277

62. Vardon DR, Sharma BK, Scott J et al (2011) Chemical properties of biocrude oil from the hydrothermal liquefaction of Spirulina algae, swine manure, and digested anaerobic sludge. Bioresour Technol 102(17):8295-8303

63. Vardon DR, Sharma BK, Blazina GV et al (2012) Thermochemical conversion of raw and defatted algal biomass via hydrothermal liquefaction and slow pyrolysis. Bioresour Technol 109:178-187

64. Jena U, Das KC, Kastner JR (2011) Effect of operating conditions of thermochemical liquefaction on biocrude production from Spirulina platensis. Bioresour Technol 102(10):6221-6229

65. Jena U, Vaidyanathan N, Chinnasamy S et al (2011) Evaluation of microalgae cultivation using recovered aqueous co-product from thermochemical liquefaction of algal biomass. Bioresour Technol 102(3):3380-3387

66. Zou SP, Wu YL, Yang MD et al (2009) Thermochemical catalytic liquefaction of the marine microalgae dunaliella tertiolecta and characterization of bio-oils. Energy Fuels 23(7):3753-3758

67. Zou SP, Wu YL, Yang MD et al (2010) Bio-oil production from sub- and supercritical water liquefaction of microalgae $D u$ naliella tertiolecta and related properties. Energy Environ Sci 3(8):1073-1078

68. Zou SP, Wu YL, Yang MD et al (2010) Production and characterization of bio-oil from hydrothermal liquefaction of microalgae Dunaliella tertiolecta cake. Energy 35(12):5406-5411

69. Chen Y, Wu YL, Zhang PL et al (2012) Direct liquefaction of Dunaliella tertiolecta for bio-oil in sub/supercritical ethanolwater. Bioresour Technol 124:190-198

70. Hognon C, Delrue F, Texier J et al (2015) Comparison of pyrolysis and hydrothermal liquefaction of Chlamydomonas reinhardtii. Growth studies on the recovered hydrothermal aqueous phase. Biomass Bioenerg 73:23-31

71. Eboibi BE, Lewis DM, Ashman PJ et al (2014) Effect of operating conditions on yield and quality of biocrude during hydrothermal liquefaction of halophytic microalga Tetraselmis sp. Bioresour Technol 170:20-29

72. Zhou D, Zhang L, Zhang SC et al (2010) Hydrothermal liquefaction of macroalgae enteromorpha prolifera to bio-oil. Energy Fuels 24(7):4054-4061

73. Yang YF, Feng CP, Inamori Y et al (2004) Analysis of energy conversion characteristics in liquefaction of algae. Resour Conserv Recycl 43(1):21-33

74. Li DM, Chen LM, Xu D et al (2012) Preparation and characteristics of bio-oil from the marine brown alga Sargassum patens C. Agardh. Bioresour Technol 104(1):737-742

75. Alba LG, Torri C, Samori C et al (2012) Hydrothermal treatment (HIT) of microalgae: evaluation of the process as conversion method in an algae biorefinery concept. Energy Fuels 26(1):642-657

76. Anastasakis K, Ross AB (2011) Hydrothermal liquefaction of the brown macro-alga Laminaria saccharina: effect of reaction conditions on product distribution and composition. Bioresour Technol 102(7):4876-4883

77. Cole A, Dinburg Y, Haynes BS et al (2016) From macroalgae to liquid fuel via waste-water remediation, hydrothermal upgrading, carbon dioxide hydrogenation and hydrotreating. Energy Environ Sci 9(5):1828-1840
78. Duan PG, Savage PE (2011) Upgrading of crude algal bio-oil in supercritical water. Bioresour Technol 102(2):1899-1906

79. Duan PG, Savage PE (2011) Catalytic hydrotreatment of crude algal bio-oil in supercritical water. Applied Catalysis B-Environmental 104(1/2):136-143

80. Duan PG, Savage PE (2011) Catalytic treatment of crude algal bio-oil in supercritical water: optimization studies. Energy Environ Sci 4(4):1447-1456

81. Li Z, Savage PE (2013) Feedstocks for fuels and chemicals from algae: treatment of crude bio-oil over HZSM-5. Algal Res 2(2):154-163

82. Patel B, Hellgardt K (2015) Hydrothermal upgrading of algae paste in a continuous flow reactor. Bioresour Technol 191:460-468

83. Duan PG, Bai XJ, Xu YP et al (2013) Catalytic upgrading of crude algal oil using platinum/gamma alumina in supercritical water. Fuel 109:225-233

84. Duan PG, Wang B, Xu YP (2015) Catalytic hydrothermal upgrading of crude bio-oils produced from different thermochemical conversion routes of microalgae. Bioresour Technol 186:58-66

85. Xu YP, Duan PG, Wang B (2015) Catalytic upgrading of pretreated algal oil with a two-component catalyst mixture in supercritical water. Algal Res 9:186-193

86. Bai XJ, Duan PG, Xu YP et al (2014) Hydrothermal catalytic processing of pretreated algal oil: a catalyst screening study. Fuel 120:141-149

87. Biller P, Sharma BK, Kunwar B et al (2015) Hydroprocessing of bio-crude from continuous hydrothermal liquefaction of microalgae. Fuel 159:197-205

88. Elliott DC, Biller P, Ross AB et al (2015) Hydrothermal liquefaction of biomass: developments from batch to continuous process. Bioresour Technol 178:147-156

89. Neveux N, Yuen AKL, Jazrawi C et al (2014) Pre- and postharvest treatment of macroalgae to improve the quality of feedstock for hydrothermal liquefaction. Algal Res 6:22-31

90. Suresh C, Santhanaraj D, Gurulakshmi M et al (2012) Mo-Ni/ Al-SBA-15 (sulfide) catalysts for hydrodenitrogenation: effect of Si/Al ratio on catalytic activity. Acs Catal 2(1):127-134

91. Sivasankar N, Prins R (2006) Reactions of mixed dialkyl- and trialkylamines over $\mathrm{Pd} / \gamma-\mathrm{Al}_{2} \mathrm{O}_{3}$. J Catal 241(2):342-355

92. Koreeda T, Kochi T, Kakiuchi F (2014) Ruthenium-catalyzed reductive deamination and tandem alkylation of aniline derivatives. J Organomet Chem 741(1):148-152

93. Li X, Lu MH, Wang AJ et al (2008) Promoting effect of $\mathrm{TiO}_{2}$ on the hydrodenitrogenation performance of nickel phosphide. J Phys Chem C 112(42):16584-16592

94. Sun ZC, Li X, Wang AJ et al (2012) The effect of $\mathrm{CeO}_{2}$ on the hydrodenitrogenation performance of bulk $\mathrm{Ni}_{2} \mathrm{P}$. Top Catal 55(14/15):1010-1021

95. Duan XP, Li X, Wang AJ et al (2010) Effect of $\mathrm{TiO}_{2}$ on hydrodenitrogenation performances of MCM-41 supported molybdenum phosphides. Catal Today 149(1/2):11-18

96. Yu GL, Zhou YS, Wei Q et al (2012) A novel method for preparing well dispersed and highly sulfided NiW hydrodenitrogenation catalyst. Catal Commun 23:48-53

97. Fang MX, Tang W, Yu CJ et al (2015) Performance of Ni-rich bimetallic phosphides on simultaneous quinoline hydrodenitrogenation and dibenzothiophene hydrodesulfurization. Fuel Process Technol 129:236-244

98. Deepa G, Sankaranarayanan TM, Shanthi K et al (2012) Hydrodenitrogenation of model $\mathrm{N}$-compounds over $\mathrm{NiO}-\mathrm{MoO}_{3}$ supported on mesoporous materials. Catal Today 198(1):252-262 
99. Liu L, Liu B, Chai Y et al (2011) Synergetic effect between sulfurized $\mathrm{Mo} / \gamma-\mathrm{Al}_{2} \mathrm{O}_{3}$ and $\mathrm{Ni} / \gamma-\mathrm{Al}_{2} \mathrm{O}_{3}$ catalysts in hydrodenitrogenation of quinoline. J Nat Gas Chem 20(2):214-217

100. Colman RC, Baldanza MAS, Schmal M (2010) Influence of Mo species on the Pt/NaY catalyst and the effect of sulfur content on the hydrodenitrogenation reaction. J Phys Chem C 114(43):18501-18508

101. Kopyscinski J, Choi J, Ding L et al (2012) Ni promotion of WP/ $\mathrm{SiO}_{2}$ catalysts for pyridine hydrodenitrogenation. Catal Lett 142(7):845-853

102. Duan PG, Savage PE (2011) Catalytic hydrothermal hydrodenitrogenation of pyridine. Appl Catal B-Environ 108(1/2):54-60

103. Deng ZG, Lei YQ, Lu XQ et al (2015) Hydrodenitrogenation of pyridine on $\operatorname{MoP}(010)$ : competition between hydrogenation and denitrification. Inorg Chim Acta 435:30-37

104. Oyama ST, Lee YK (2005) Mechanism of hydrodenitrogenation on phosphides and sulfides. J Phys Chem B 109(6):2109-2119

105. Abu II, Smith KJ (2007) Hydrodenitrogenation of carbazole over a series of bulk $\mathrm{Ni}_{x} \mathrm{MoP}$ catalysts. Catal Today $125(3 /$ 4):248-255

106. Lewandowski M (2015) Hydrotreating activity of bulk NiB alloy in model reaction of hydrodenitrogenation of carbazole. Appl Catal B-Environ 68:322-332

107. Abu II, Smith KJ (2007) HDN and HDS of model compounds and light gas oil derived from Athabasca bitumen using supported metal phosphide catalysts. Appl Catal A 328(1):58-67

108. Costanzo W, Hilten R, Jena U et al (2016) Effect of low temperature hydrothermal liquefaction on catalytic hydrodenitrogenation of algae biocrude and model macromolecules. Algal Res 13:53-68

109. Rashidi S, Nikou MRK, Anvaripour B (2015) Adsorptive desulfurization and denitrogenation of model fuel using HPW and NiO-HPW modified aluminosilicate mesostructures. Microporous Mesoporous Mater 211:134-141

110. Vilas M, Gonzalez EJ, Tojo E (2015) Extractive denitrogenation of model oils with tetraalkyl substituted pyridinium based ionic liquids. Fluid Phase Equilib 396:66-73

111. Ahmed I, Jhung SH (2015) Remarkable improvement in adsorptive denitrogenation of model fossil fuels with $\mathrm{CuCl} / \mathrm{ac}-$ tivated carbon, prepared under ambient condition. Chem Eng $\mathrm{J}$ 279:327-334

112. Han X, Lin HF, Zheng Y (2015) Adsorptive denitrogenation and desulfurization of diesel using activated carbons oxidized by $\left(\mathrm{NH}_{4}\right)_{2} \mathrm{~S}_{2} \mathrm{O}_{8}$ under mild conditions. Can $\mathrm{J}$ Chem Eng 93(3):538-548

113. Han X, Lin HF, Zheng Y (2015) The role of oxygen functional groups in the adsorption of heteroaromatic nitrogen compounds. J Hazard Mater 297:217-223

114. Bae YS, Kim MB, Lee HJ et al (2006) Adsorptive denitrogenation of light gas oil by silica-zirconia cogel. AIChE J 52(2):510-521

115. Koriakin A, Ponvel KM, Lee CH (2010) Denitrogenation of raw diesel fuel by lithium-modified mesoporous silica. Chem Eng J 162(2):649-655

116. Rizwan D, Dalai AK, Adjaye J (2013) Synthesis of novel polymer poly(glycidyl methacrylate) incorporated with tetranitrofluorenone for selective removal of neutral nitrogen species from bitumen-derived heavy gas oil. Fuel Process Technol 106(2):483-489

117. Xie LL, Favre-Reguillon A, Wang XX et al (2010) Selective adsorption of neutral nitrogen compounds from fuel using ionexchange resins. J Chem Eng Data 55(11):4849-4853

118. Arcibar-Orozco JA, Rangel-Mendez JR (2013) Model diesel denitrogenation by modified activated carbon with iron nanoparticles: sulfur compounds effect. Chem Eng J 230:439-446

119. Wang ZY, Sun ZG, Kong LH et al (2013) Adsorptive removal of nitrogen-containing compounds from fuel by metal-organic frameworks. J Energy Chem 22(6):869-875

120. Zhang H, Song HY (2012) Study of adsorptive denitrogenation of diesel fuel over mesoporous molecular sieves based on breakthrough curves. Ind Eng Chem Res 51(49):16059-16065

121. Ahmed I, Khan NA, Hasan Z et al (2013) Adsorptive denitrogenation of model fuels with porous metal-organic framework (MOF) MIL-101 impregnated with phosphotungstic acid: effect of acid site inclusion. J Hazard Mater 250:37-44

122. Ahmed I, Hasan Z, Khan NA et al (2013) Adsorptive denitrogenation of model fuels with porous metal-organic frameworks (MOFs): effect of acidity and basicity of MOFs. Appl Catal B 129:123-129

123. Nuzhdin AL, Kovalenko KA, Dybtsev DN et al (2010) Removal of nitrogen compounds from liquid hydrocarbon streams by selective sorption on metal-organic framework MIL-101. Mendeleev Commun 20(1):57-58

124. Chen WT, Tang LY, Qian WY et al (2016) Extract nitrogencontaining compounds in biocrude oil converted from wet biowaste via hydrothermal liquefaction. Acs Sustain Chem Eng 4(4):2182-2219

125. Neveux N, Magnusson M, Maschmeyer T et al (2015) Comparing the potential production and value of high-energy liquid fuels and protein from marine and freshwater macroalgae. Glob Change Bioly Bioenergy 7(4):673-689

126. Hansmeier AR, Meindersma GW (2011) de Haan AB (2011) Desulfurization and denitrogenation of gasoline and diesel fuels by means of ionic liquids. Green Chem 13(7):1907-1913

127. Huh ES, Zazybin A, Palgunadi J et al (2009) Zn-containing ionic liquids for the extractive denitrogenation of a model oil: a mechanistic consideration. Energy Fuels 23(6):3032-3038

128. Asumana C, Yu GR, Guan YW et al (2011) Extractive denitrogenation of fuel oils with dicyanamide-based ionic liquids. Green Chem 13(11):3300-3305

129. Matsumoto M, Mikami M, Kondo K (2006) Separation of organic nitrogen compounds by supported liquid membranes based on ionic liquids. Bull Jpn Petrol Inst 49(5):256-261

130. Rogalinski T, Herrmann S, Brunner G (2005) Production of amino acids from bovine serum albumin by continuous subcritical water hydrolysis. J Supercrit Fluids 36(1):49-58

131. Ojha KS, Alvarez C, Kumar P et al (2016) Effect of enzymatic hydrolysis on the production of free amino acids from boarfish (Capros aper) using second order polynomial regression models. LWT Food Sci Technol 68:470-476

132. Vispute TP, Zhang HY, Sanna A et al (2010) Renewable chemical commodity feedstocks from integrated catalytic processing of pyrolysis oils. Science 330(6008):1222-1227 